\title{
Digitizing the Social Contract: Producing American Political Culture in the Age of New Media
}

\author{
Philip N. Howard \\ Department of Communication \\ University of Washington
}

$10 / 22 / 2017$

\begin{abstract}
Campaigns are complex exercises in the creation, transmission, and mutation of significant political symbols. However, there are important differences between political communication through new media and political communication through traditional media. Many scholars who study the political role of new media look for changes in voter sophistication, news consumption patterns, or habits of learning about politics, but they have found few discernable 'media effects'. They have found few changes as these communication tools have diffused. I argue that the most interesting change in patterns of political communication is in the way political culture is produced, not in the way it is consumed. These interesting changes are best observed through systematic ethnography, so I present findings from two organizations devoted to digitizing the social contract. DataBank.com is a private data mining company that used to offer its services to wealthier campaigns, but can now sell data to the smallest nascent grassroots movements and individuals. Astroturf-Lobby.org is a political action committee that helps lobbyists seek legislative relief to grievances by helping these groups find and mobilize their sympathetic publics. I analyze the range of new media tools for producing political culture, and with this ethnographic evidence build two theories about the role of new media in advanced democracies - a theory of thin citizenship and a theory about data shadows as a means of political representation.
\end{abstract}

\section{Introduction}

Technological innovations can radically alter the organization of power in politics. Most scholars of political campaigning make distinctions between the pre-modern campaign, the modern campaign, and the postmodern campaign. Between the mid-19th century and 1950 , local party volunteers took the pulse of member opinion with party meetings and local canvassing efforts. Very little centralized control of campaign logistics existed. The news media comprised a partisan press, radio, and local posters or pamphleteers, who brought relatively low budget, local public meetings and whistle-stop leadership tours to the attention of a stable, partisan electorate. Modern campaigns, run between the 1960 s and late 1980s, were long, nationally coordinated campaigns run by professional consultants and specialist advisors from a central party headquarters. Occasional opinion polls helped the campaign keep on top of public sentiments, and the nightly television news broadcasts were the most important medium for publicizing closely managed campaign events. The costs of these campaigns grew immensely to fund televised media events and political commercials, which had to target increasingly fickle cross-sections of 
the electorate. The postmodern campaigns that developed in the 1990s remained nationally coordinated but became operationally decentralized. Presidential campaigns, in particular, currently have a permanent quality, applying impression-management strategies from the beginning of primary contests, through the election cycle, through the term of office, to legacy campaigns or preparation for the subsequent electoral contest. Ever more professional consultants use regular opinion polls and focus groups to produce ever more costly targeted campaign television ads and events, trying to manage news production for segments of the electorate that are no longer in stable party alignments (Norris, 2000), p. 139.

However, the term 'postmodern' is a vague descriptor. I would rather use the term 'hypermedia campaign' to describe the political communication systems developed in the early 1990s and still in use today. The dominant feature of the new campaign is not, as Norris describes, costly targeted campaign television ads, but instead cheap, targeted campaign ads over the Internet. Such costly television ads were an exaggerated feature of the late modern campaign. Today's campaign is more reflexive, less costly, and operates in a political sphere with fewer (media-based) barriers to entry. But another theme must also hold our attention: political culture in the hypermedia campaign is consumed by the producer and produced by the consumer. The exercise of producing and consuming political culture is conflated: it is done by the same people, people of varying amounts of financial, human, and social capital.

Grossman's The Electronic Republic argues that we are moving into a third stage of democratic evolution. The early direct democracies evolved into representative democracies, and the new electronic media will bring us to a wired reincarnation of direct democracy. "Telecommunications can give every citizen the opportunity to place questions of their own on the public agenda and participate in discussions with experts, policy-makers and fellow citizens" (Grossman, 1996) p. 48). However, he recognized that it would take a deliberate effort to get technology to work in this way. Whether or not we accept the pundit's enthusiasm for wired democracy, even the headiest theories of deliberative democracy argue that communications infrastructure can either be the great hope or great bane of discourse. Robert Dahl, in Democracy and Its Critics, argues that the ability of communications technology to make information available to the public, both in a timely and accessible manner, can be harnessed to promote democratic values (Dahl, 1989). In Republic.com, Sunstein argues that in the wired democracy citizens will only receive political messages from deliberately chosen sources (Sunstein, 2001). But one of the latest trade books about wired contemporary culture, Rhiengold's Smart Mobs, makes an optimistic argument about informational agility in the public sphere (Rheingold, 2002). Putnam's Bowling Alone also makes hopeful references to the possibilities inherent in a wired public sphere (Putnam, 2000).

DiMaggio and others have argued that empirical study of the social context for new media is important for three reasons (DiMaggio, Hargittai, Neuman, \& Robinson, 2001). First, the moment is ripe for studying the growth, diffusion, and institutionalization of a new communication medium while the new medium is occurring. Second, not only is the medium uniquely interesting for its multiple modes of communication (reciprocal 
interaction, broadcasting, individual reference-searching, group discussion, person/machine interaction) and kinds of content (text, video, images, audio) but, because of this diversity, its reach and impact may be socially deeper than other media such as radio and television. Third, many of the design choices being made today will pattern the way the Internet is used for decades to come, and understanding the normative structures and social assumptions of the designers will have both theoretical implications for our understanding of how culture is built and policy implications for the conduct of the social sphere online.

One might argue that patterns in the production and consumption of political culture have always been fluid, and any claim to having found a 'new political culture' must acknowledge that some trends are decades old. The demise of class politics and clientelism, diminishing party loyalties, and the rise of consumer and lifestyle issues and 'Third Way' politics can be traced back to the 1970s (Clark, Hoffmann-Martinot, \& Gromala, 1998). However, television communication systems, largely managed by political and media elites, have served to constrain healthy political discourse. The candidates sent messages and the viewing public received the messages. Information had a relatively short life; television campaigning is fleeting and difficult to verify. In contrast, the age of cyber-politics is supposed to be inherently democratic and aterritorial: debating substantive political issues in an electronic forum may allow participants to hide cues about race, gender and other forms of social inequality that are known to affect faceto-face communication; where a political position is already agreed upon, the community can coordinate their activism across geographies and time zones. Candidates and citizens send and seek data about each other's preferences and voting histories. Cyber-politics turn at a much faster pace, and political elites have less control of spin and impact because the medium relies on citizenry for message turnover. Massive volumes of information can be stored and easily accessed, making it possible to verify campaign messages, and, presumably, catch lies and mistakes. But beyond the punditry, what role does the hypermedia campaign have in the public sphere?

I argue that the way political culture is produced has fundamentally changed through the growing use of Internet technologies in campaigning. Two particular companies DataBank.com and Astroturf-Lobby.org - are good examples of the kinds of tools being developed for contemporary campaign communications. These two consultancies help organize political power in new ways. those who have traditionally held control of political knowledge have lost much of this control to those with the ability to design and operate political hypermedia. The production of political culture is increasingly the purview of either technocrats, whose choices about technology design affect the distribution of political power, or non-traditional actors, who -- equipped with political hypermedia -- exercise the same marketing capacity as traditional political actors. The new system of producing political culture has implications for the meaning of citizenship and the basis of representation.

This article is divided into three sections. First, I review some of the recent scholarship on political communication and our search for political 'media effects' of the Internet and database technologies. Subsequently, I introduce the concept of political hypermedia 
to describe a range of communication tools with similar properties. Second, I introduce two organizations, one consulting firm and one political action committee, and I use some of my ethnographic observations and interview notes to reveal the design norms behind political hypermedia. In the third section, I analyze these two case studies and the role of political hypermedia in producing political culture. I contrast the established practices for public opinion measurement with the new science of private opinion measurement, and develop two theories of citizenship suitable for understanding the meaning of franchise in a political culture produced through hypermedia.

\section{The Search for New Media Effects}

The political Internet emerged dramatically between the 1996 and 2000 presidential campaigns. The proportion of people using the Internet to collect news or research policy alternatives increased significantly as the technology diffused. Exit polls in 2000 revealed that a third of the electorate used the Internet to do some kind of research on candidates (Howard, Jones, \& Rainie, 2001). From inside the campaigns, the Internet and related Internet tools let a number of campaigns make significant advances in fundraising, volunteer coordination, logistics, and opposition research (Witte \& Howard, 2002). As journalists began to cover the campaign season, they produced many stories about the new digital democracy, hypermedia campaign, and cyber activist. Political life, headlines declared, was being revolutionized by the Internet technologies. Just as the new economy had become a fast-paced, interactive system in which traditional economic elites had to battle with young creative start-ups for the attention of the informationsavvy consumer, politics was becoming a fast-paced, interactive system in which traditional political elites had to engage with new actors to build creative policy options for the information-savvy citizen.

In the United States, academic interest in 'media effects' began in earnest in the middle of last century with Merton, Lazarsfeld, Katz and other political socialists who constituted the Columbia School and turned to studying the television and other outlets of popular culture (Lazarsfeld \& Merton, 1948; Merton, Lowenthal, \& Curtis, 1946). Lippman and Dewey agreed that the machine age, symbolized by steam, cable, telephone, radio, railroads, inexpensive printing, and mass production brought about new forms of political engagement, and their debates over the nature of deliberative democracy early in the last century set up many of the early debates in the discipline of political science. In 1937, Ogburn published a study that reflects the analytical inclination to look at the independent effects of 'things' on social institutions and draw broad sweeping conclusions:

Government in the United States will probably tend toward greater centralization because of the airplane, the bus, the truck, the Diesel engine, the radio, the telephone, and the various uses to which the wire and wireless may be placed. The same inventions operate to influence industries to spread across state lines... The centralizing tendency of government seems to be world-wide, wherever modern transportation and communication exist. (Ogburn, 1937) 
Theorists such as Tarde, Habermas, and Anderson have enunciated a fairly clear sense of what makes a healthy public sphere. The public sphere is a space where people exchange ideas and challenge one another's opinions. First, it requires shared text, regularly published and generally accessible; citizens must be confident that the text is indeed shared across the polity so that everyone has access to the same quality of information. Second, it requires the act of conversation, through which we constitute the public sphere when we discuss the affairs of state and share the floor without discrimination. For practical reasons, we agree to mediating institutions like pollsters and newspaper editors, who assist the act of conversation by helping distill opinion and present distinct, coherent policy options. Third, a healthy public sphere requires the space for action, legislatures, courts, voting booths, and places of administration where decisions are made and enacted (Anderson, 1991; Habermas, 1991; Katz, 1992; Tarde, 1898). The more of these spheres the better, says Calhoun, so that different people can communicate their needs to one another (Calhoun, 1998).

Positive Political Effects. The argument that the Internet technologies are good for democracy is grounded in the claim that the technologies can mitigate some of the more debilitating features of contemporary political communication. Anything that will overcome the effects of unidirectional media or inadequate information supplies will help democratic deliberation. Some argue that virtual communities can only add to the public sphere (Schwartz, 1996), especially when they grow around bulletin boards for exchanging ideas, mobilizing the public, and building social capital (Rheingold, 1993, 2002). Redd argues that African American families in particular can equalize their relationships with corporate American and political elites with an accessible communications media rich in information (Redd, 1988). Studies of local activism have revealed that Internet tools facilitate social networking across traditional socioeconomic boundaries, engage people with group learning experiences, and draw new participants into public life (Brants, Huizenga, \& van Meerten, 1996; Mele, 1999; Tsagarousianou, Tambini, \& Bryan, 1998; Wittig \& Schmitz, 1996). People who use new media avoid the harmful effects of traditional media, especially television, by experiencing politics in a more direct and interactive forum. The Internet reduces the distance between the governed and government (Budge, 1996; Grossman, 1996). Television news seems to have more of an influence on public concern than vice versa (Behr, 1985; Fallows, 1996; Mutz, 1995), so a multidirectional medium might create a news agenda that reflects public interests. Whereas traditional media have a reinforcing effect that benefits political parties (Burbank, 1997), Internet technologies permit users to create new social contexts for themselves based outside neighborhood, friends, and family, through which they might convert to minority partisans or independent political positions. Moreover, rather than becoming fully informed, many voters rely on media cues and informational short cuts, to the overall benefit of incumbent presidents and Democratic candidates (Bartels, 1996; Lupia, 1994). Citizens have an inadequate supply of information from traditional news sources, limited opportunities to interact with public policy officials, and few opportunities to deliberate with each other -- each of these problems in information supply can be overcome with the Internet. Many new media technologies open up possibilities for new forms of governance and representation. If these kind of theories 
about mobilization are correct, we would expect to see more people getting involved, more people voting, voters with better or more information, and new types of nongovernmental agencies and civic groups.

Negative Political Effects. Some have argued that the Internet is at best a global shopping mall and at worst a den of inequity. The political content online is a base kind of political pornography in which information is grossly simplified, easily misrepresented, and often perverted. Those who deplore the role of the Internet in contemporary politics argue that specific tools - especially email - can incapacitate political offices. In 2000, Capitol Hill received more than 6.5 million messages a month, about 8,000 per representative and 55,000 per senator, a volume that had doubled over the previous two years (Goldschmidt, 2001). When a website visitor is known to support second-ammendment rights, they are shown news about how guns are used to save lives, while website visitors who are known to hate guns get stories about accidental shootings. Mud slinging will always occur over any media, but many new media have the additional benefit of obscuring authorship or making the content creator anonymous (Tumber \& Bromley, 1998). For example, during the 2000 election campaign, the Republicans were responsible for the websites gorewillsayanything.com, gorereinventionconvention.com, and gorepollution.com, while the Democrats produced iknowwhatyoudidintexas.com and millionairesforbush.com. In other words, Internet technologies exacerbate and reinforce current political trends. No amount of innovative Internet technology can overcome the existing knowledge gap that prevents lower-educated and information-poor groups from learning quickly during a campaign period, instead leaving them more susceptible to manipulation by political advertisements (Moore, 1987; Tichenor, Donohue, \& Olien, 1970). Some have concluded that the networked communication technologies can only exacerbate the worst features of industrial capitalism, in part because the culture of information exchange on the Internet is driven by the commercial ethic of selling information (Barney, 2000; Gutstein, 1999). Those communities that do form online are at best 'pseudo-communities' that are intensely interpersonal or mass communication systems that are more intimate but allow for more effective social control (Beniger, 1987). Since only the most politically extreme voters make use of information resources and the most informed citizens actually vote (Palfrey \& Poole, 1987), we can expect that when the Internet provides widespread access to informational resources, political life will become a clash of the most opinionated, not a dialogue of the self-taught and inquisitive. On an individual level, some researchers argue that the Internet reduces social involvement and psychological well being, which certainly could not be good for the future of the deliberative democracy (Kraut et al., 1998).

No Political Effects. Others have argued that there are few or negligible distinct 'media effects' and all that is good and bad about political life in America can be replicated online (Margolis, 1997). No legislative initiative exists to build a fifth wing of government specifically designed within the checks and balances system to institutionalize Internet tools in political life with regular, sanctioned public opinion measurement by government organizations. There will be no direct democracy Internet voting in the near future. The Internet has no particular impact. Process may be faster, or more efficient, but does not itself make voters more sophisticated or more likely to 
participate. Ultimately, this is the position I take in this article: Internet technologies are not agents, but structures. They do not cause, but they do pattern, social outcomes.

Besides, inequalities or biases of information levels in the electorate are the real threat to sound electoral decision-making, not low levels of information (Miller, 1986). This has been called the "C-SPAN" effect: despite the broadcast of substantive legislative deliberations from coast to coast, few people watch the deliberations and no measures of political sophistication show improvements since the channel went live. There is a large community of "know-nothings" who do not understand politics enough to value democratic deliberation or participate in it (Bennett, 1988). Regardless of the medium involved, there are substantial differences in information processing skills regarding political issues (MacKuen, 1984). However, several senior scholars who have entered the debate over the societal effects of the Internet have sought to polarize opinion between a "connection with the world" position (Etzioni, 2000) and a "shrinking social universe" position (Nie \& Erbring, 2000).

A number of experiments and small projects have demonstrated that Internet technologies have immense potential for helping grass-roots activism (Arterton \& Roosevelt Center for American Policy Studies., 1987; Downing, 1989; Downing, 1991; McGrath, 2000). But there is a significant difference between experimenting with particular technology systems like email or USENET in a controlled environment and understanding deeper cultural change across a society (Groper, 1996; Hill \& Hughes, 1997). The few pieces that are grounded in lived experience were conducted before new media technologies were part of the mainstream political process (Rash, 1997), and many are speculative and anecdotal exercises in futurism (Graber, 1996; Gray, 2001; Toffler, 1990; Toffler \& Toffler, 1995). There are several edited collections full of small case studies but no large study with a systematic cultural method (Alexander \& Pal, 1998; Davis \& Owen, 1998; Dijk \& Hacker, 2000; Ferdinand, 2001; Kamarck, Nye, \& Visions of Governance in the 21 st Century (Program), 2002; Moll \& Shade, 2001). In addition, there are a number of 'sited' trade books (Kidder, 1981; Miles, 2001)

The other approach has been to study discourse to clarify and qualify the concept of 'electronic democracy' and 'virtual state' (Barney, 2000; Everard, 2000; Friedland, 1996; Gutstein, 1999; Hacker, 1996; Hague \& Loader, 1999; Sunstein, 2001; Tambini, 1999; Tehranian, 1990). These studies help us map out the range of social possibilities and imagine the future, yet without systematically introducing us to phenomena of the present and enacted. Often they are analyses of rhetorical claims or well-articulated hypothetical scenarios based on what is known and possible in computer-mediated communication systems. In political science, some studies have taken up the possible role of Internet technologies in public deliberation (Bimber, 1998). Critical thinkers try to channel discourse by warning that we need to be aware that how we define digital democracy affects our expectations of it, that electronic technology may favor categorical identities more than dense social networks (Calhoun, 1998). Most of these kinds of studies give us a set of conditions for improving democracy with the Internet: technologies have to be made interactive and accessible, and have to be designed, from the bottom up, specifically to serve deliberative, democratic institutions. But despite all the principled discussion on how Internet technologies 'can' be designed to improve democratic 
discourse with the right regulatory and economic context, there have been few studies on how or if this is being done.

NEW HEADINGThe Profession of Political Consulting

Whether or not Internet effects exist, the political consulting industry took the Internet seriously. Conferences (Corrado, 1996), strategy books (Bennett \& Fielding, 1999; Ireland \& Nash, 2001; Walch, 1999), industry research reports (Faucheux, 1998; Jagoda, 2000; Jagoda \& Nyhan, 1999; Multiple, 1999), seminars from freelance net advocates (Clift, 2000)DELETE CLIFT, think tanks (Norman, 1989), and major management consultants (Accenture, 2001) helped prepare political campaigns for the $21^{\text {st }}$ century. The application of the Internet technologies in political life has also allowed some of the larger corporate identities to glom onto political ideas. Through advertising campaigns, Microsoft and Accenture Consulting are now associated, beyond their economic services, with the advancement of a healthy public sphere and deliberative democracy. Pundits covered the arrival of electronic democracy (Ganly, 1991; Heclo, 1999; Milban, 1999; Shapiro, 1999; Wright, 1995), making celebrities of the new breed of political consultants - the ones who could write HTML (Lewis, 2001; Ransell, 1999; Wasserman, 1999). Many of these publications read as if a small part of the political culture industry was trying to teach campaign staff - and the wider public - what to dream about and expect from the new wired democracy. The summer before the campaign season USA Today declared, "Getting on line is so simple a 'kid with an attitude' can organize a political force" (Drinkard, 1999). The dreams are big, but there is also some distance between what is hoped, what is theorized, and what is observable, making a systematic ethnography a valuable research exercise.

We are still left with the broad question, similar to the interesting query taken up by Merton and Lazarsfeld fifty years ago - what are the implications of this significant new communications media for the health of the public sphere? To do this, I did a 'network ethnography' of the small group of specialists who managed many of the important Internet campaigns in the presidential race of the year 2000 (Howard, 2002). I spent the 2000 election cycle (which began in the fall of 1999 and ended in January 2001) within the community of professional consultants who specialize in using new media for campaign logistics and political communication. I conducted participant observation at dozens of specialist conferences and the major national party conventions, ethnography within specific political hypermedia projects, and interviews with thirty-five of the most important consultants in the business.

Political communication scholarship has been focused on the individual experience of politics online and the average person's changing news habits because its case studies have been too dependent on the attributes or environments of singular technologies. Particular technologies have users, and studying a particular technology may reveal how an individual user experiences or contributes to democratic deliberation. I start with a more inclusive definition that contextualizes multiple technologies as part of a larger system for collecting and distributing political information. Political hypermedia are the conjoined superstructure of fast, high-capacity hardware and software communication tools lets people transmit, interact with, and filter data. First, new media are structured 
literally over and above traditional media in a network of satellites, relay stations, and databases that coordinate the retrieval and delivery of public and private information. Second, these media operate at greater speeds and with greater amounts of content than do traditional media. Third, they permit simulations of offline interaction, speedy circulation of social signs and meanings, rapid decomposition and recomposition of messages, and increased transience of socially significant symbols (Howard, 2002). Treating political hypermedia as a system of networked tools allows us to generalize in ways not possible in studies of particular tools. And one of the best ways to understand the design principles of this technological system is through two representative organizations, DataBank.com and Astroturf-Lobby.org. Their work reveals two principles of citizenship on which political hypermedia are based: a thin model of citizenship that privileges the opinion of strategically located voters who may only have cursory knowledge or formed opinions with little deliberation; a shadow model of citizenship that collects and calculates political preferences from the data trail we leave, anticipating political opinion without directly approaching voters and allowing formal deliberation.

\section{Digitizing the Social Contract}

Rousseau's notion of a social contract, into which we enter when we participate in any kind of organization, is often set in contrast to Hobbes' notion of the Leviathan state hegemon that protects us and shepherds us through a life that would otherwise be nasty, brutish, and short. Hobbes' state of nature being dominated by passions, woe, and madness was in sharp contrast to Rousseau's stable political order in which people contract with one another to defer political authority to leaders who acted in good faith. Both the French and American Revolutions were political events in which citizens fundamentally redrafted the terms of their social contract, codifying the contractual roles and responsibilities of both citizens and leaders in foundational documents like the Declaration of the Rights of Man or the Declaration of Independence. Of course, a small group of people actually drafted the terms of new social contracts, but they worked under the assumption that citizens at large were entering into an agreement that would be monitored and enforced by a range of institutions.

Many of the consultants who specialize in political hypermedia imagine that they are digitizing the social contract, bringing it into the $21^{\text {st }}$ century, and in the late $1990 \mathrm{~s}$ they began to meet to talk about their electronic revolution in the back of a dimly lit pub in the Dupont Circle neighborhood of Washington, DC. The pub was called the Childe Herold, after Byron's homage to Rousseau, and while their meetings did not produce any grand revolutionary declarations, they did begin to enunciate the terms under which the social contract would be executed in the digital age. I argue that the engineers of political hypermedia are building new tools for the production of political culture under the assumption that political life should obey the rules of a social contract. Communication tools that help citizens comparison shop for political candidates or help political leaders measure political attitudes help in the execution of this contract. 


\section{A. The Opportunists at DataBank.com}

DataBank.com recently adopted its new name. ${ }^{1}$ For more than a decade the firm was one of the top direct mail companies, having helped put several presidents and hundreds of senators, representatives, and governors into their offices. From the start, the founder, Larry had used computing equipment to store political and demographic information, but as stand-alone computing power improved, and then grew networked, Larry was able to deepen his databases and make them relational - linking multiple sources of data through multiple kinds of cases. In 1999 the firm went online, offering online access to its data services for the modern campaigns that need to feed on data 24 hours a day.

I had to work to convince Larry and the other staff that my research objective was not necessarily to expose or embarrass them. Many newspaper articles had profiled their operations and some members of the professional community though their work violated even the lowest privacy expectations. That their seed capital came from credit card companies is often held against them. But one of the reasons I chose Databank.com to observe is that its customers are successful, which is seen as the best form of advertisement in this industry. The firm is high profile -- even for DC its offices are unusually secure with shaded windows, multiple locked entrances, and expensive computer security services. The 24-hour demands of clients around the country require that someone always be on call. Larry told me he had several motives when he finally granted me access:

Larry: I actually try to publish our research. Collaborating with academics gives us credibility, though we have been screwed by journalists looking for a sensational story. What we are doing here is innovative and once in a while I see that even traditional pollsters are experimenting with new media survey instruments.

Larry is clearly aware that his work violates common privacy norms, and he thinks academic collaboration will help legitimize his business. As an example, he gave me an article by the head of the Harris Poll, one of the world's oldest and largest public policy polling firms, on using the Internet for marketing research (Taylor, 2000). The sensational coverage DataBank.com sometimes gets concerns its "skilled data mining." Data mining is research into the implicit and emergent information that resides in a dataset compiled from multiple sources originally collected for other explicit purposes. Different organizations have collected an immense amount of personal data for many years, and increasingly, the data is digital. Larry and has made a business of compiling and analyzing this data on voters.

Database Manager. The Database Manager is a software tool for archiving data and relating datapoints about demographics and policy preferences at different levels of aggregation, so as to extrapolate individual demographics and policy preferences from group data or generalize from individual demographics and policy preferences to group

\footnotetext{
${ }^{1}$ Corporate and individual identities are masked by pseudonyms to respect the confidentiality promised to subjects. DataBank.com and Astroturf-Lobby.org are pseudonyms based aggregates of my study of 18 consultancies specializing in political information and communication technologies between 1999-2003.
} 
attributes. Dave, Larry's first employee, described three stages in the evolution of their Database Manager tool. Early on they had very basic material: names, phone numbers, addresses, political leanings, and some demographics. Eventually they merged several large private databases, mostly about consumer activity and public health records, producing more layers on political and market behavior. More recently, they have been able to collect highly nuanced data on political preferences from the Internet by inviting voters to complete detailed political profiles in exchange for goods and services. They started out in the early 1980s with an addressing service for direct mail. The most devout Republicans and Democrats in a district would hand in their mailing addresses and phone numbers, and Larry and Dave would maintain records and sell them to candidates and campaigns as necessary. In the mid-1980s they met a prominent political scientist who wanted to conduct a survey with the nation-wide samples they had collected. The condition of making their database available was that they would get to see the results. The response rate was not great, but Larry and Dave mapped responses back into respondents, turning their list of mailing addresses into a political database. The next campaign that approached them for help was offered access to the opinion data from several key districts. The campaign staff was pleased and won their issue, so Larry and Dave hired several people to start looking for other sources of voter data.

Dave: Obviously we knew who were registered voters. On top of addresses and political affiliation we started layering whatever else we could find. The most difficult thing was figuring out how to maintain sensible 'cases' in the database. We wanted each case to be an individual. But often census data, social science data, newspaper polls comes in aggregated forms so that people can't do precisely what we were doing reverse engineer survey responses. We maintained individuals as cases, but often individuals were given attributes that were averaged variables for the community around them - family, block, neighborhood, zip code, electoral district, municipality, county, state, region.

Sally: I was one of the first data-scouts they hired. They hired four of us and our only job was to look for data. Newspapers, think tank reports, social science surveys, marketing research, anything that was politically or demographically relevant we coded and entered. We had a code for data quality. After two years of merging databases the company had an incredible resource.

These statements reveal that the relational database was designed to be scalable, so that clients with strategic needs in specific electoral districts would have the most relevant aggregated or disaggregated data. Moreover, Dave and Sally reveal the multiple sources of data in seemingly unrelated topics can be preserved and related on the basis of complex categories of social identity. By the late 1980s Larry and Dave had impressed a number of large firms and important candidates with their alacrity in helping campaigns win. But operations were expensive and the database was getting unwieldy. Larry reveals that many of the layers were from questionable sources, and also that there were 
other desirable privately held data sources available: credit card data and other forms of commercial data.

Larry: We had grown as much as we could. We had a great system of inputting data as we ran across it. Pollsters would occasionally share their stuff, but the next level was to merge with something deep, something long-term and comprehensive. As a business we suffered between campaign seasons. I was sick of hiring student interns.

The best privately held firms with large customer bases and firms that had to actively lobby government to protect their market share held the best databases in the country. These firms collected data on their customers, partly to improve customer services, and partly to equip their lobbyists with information. Ostensibly their customers were someone else's constituents.

Dave: We had helped an alliance of credit card firms stifle a Congressional privacy initiative several years back. They had produced information about constituents in key districts for the specific campaign but wouldn't let us look at the raw data. Both of us knew that with records on purchasing habits going back decades, they had one of the most potent private databases in the world. We needed them next.

They convinced one of the subsidiaries to invest in the company. In exchange for access to credit histories, Databank.com offered up a significant interest in the firm. Sally reveals that she and here bosses were trying to find consulting opportunities for their firm by inferring political opinions from private shopping habits.

Sally: Most income data is self-reported and I don't think much of that. But that's company's data was amazing! Sensibly calculated estimates of income, classifications of luxury purchases, health-related purchases we could analyze for the health lobby, gun purchases we could analyze for the gun lobby, gas purchases we could analyze for the oil lobby, and so on.

As the technology improved Databank.com has been able to merge more detailed and varied forms of information. More important, the quality of data has gone from being broadly demographic (such as class, race, gender, and general political attitudes) to psychographic (such as policy preferences, political sophistication, and parenting style). Today, DataBank.com has basic information on 150 million registered voters and more detailed profiles on 4 of every 10 American adults. Campaigns can buy two variables on a thousand people for about 50 cents, though this data can also be aggregated from an individual to household, city block, zip code, Congressional district or state. However, the data that Larry and Dave prepare for political campaigns has come a) from sources where Americans gave explicit informed consent for its immediate use but not for extended and relational use and b) from sources where Americans did not give informed consent but have nonetheless left a data trail, primarily from credit card purchases and website visits. Recently, Databank.com has made its service available over the World 
Wide Web, so that customers can directly access and pay for the data they want. ${ }^{2}$ Larry and Dave say they are especially proud of their online services because now everyone has access to data that was once only available to presidential candidates and big budget campaigns. In other words, anyone can be a customer.

Message Tester. The Message Tester software is an application that distributes a range of possible campaign ads to a representative sample of voters and canvases those voters to see how they pick up on subtle variations in political messages. More recently, Larry and Dave began experimenting with ways of using new media to test political messages. The more traditional consulting firms run focus groups for certain clients, but this is an expensive procedure not guaranteeing representative results. Rather than present 10 people with a campaign ad and get their feedback face-to-face, why not run the ad to a thousand people and measure their feedback?

Larry: Campaigns go to a lot of difficulty to test a message. They have always 'practiced' delivery. Candidates rehearse their speeches in front of test audiences, and political parties have thrown position scenarios by focus groups. The latter is especially necessary for bigger groups that have to be careful with positioning that satisfies both financial supporters and electoral supporters. Those are different groups with different interests.

Here Larry reveals how political hypermedia plays an important role in contemporary campaign strategy - negative ads, potential running-mates, policy positions are empirically tested on subpopulations through a range of text, audio and video material. Using the information they already had on the electorate, DataBank.com strategically distributed free WebTV boxes to key households across the United States. In exchange for free access to the Internet, members of the household might be subject to a survey once a week.

Dave: The WebTV boxes arrive at the door and are easy to install. The first survey they do, as part of the set-up, establishes the demographics within the household and the environment in which the WebTV box is set up. This helps us know what kind of people we could ask after, and helps control the survey environment. The box sits on top of the TV, and once a week a little red light on top of the box flashes on, indicating that someone in the household is needed for a survey.

Here Dave reveals how much thought he and his designers have put into controlling the test-taking environment of their subjects. In the first few months of the program they experimented with instrument effects by varying colors, pictures, music, and video stimuli. For a long time they could not build a random sample but they could build

\footnotetext{
${ }^{2}$ DataBank.com, and the PAC Astroturf-Lobby.org discussed below, are very careful to obey state laws that regulate which records can be sold to whom. Both firms have legal counsel committed to keeping the company's work well within the letter and spirit of the law.
} 
purposive samples and had other techniques for getting close to the most important goal a representative sample (Witte \& Howard, 2002).

I met someone from a major lobby group in the DataBank.com offices late one Friday in May. He was in to pick up a test report that several Databank.com staffers had spent all night on. The lobbyist told me, "I'd much rather work with recent private information and reactions to my ads than models based on old publicly available data." On Monday the lobby group decided they needed to run some issue ads as soon as possible. They scripted four possible ads, each with different levels of message strength. On Tuesday they produced the 30 -second radio spots at a studio in New York. On Wednesday the spots were beamed to DataBank.com's offices and put to a purposive sample of 200 households in Chicago, where the lobby wanted to be heard. By Thursday night results were coming in: the DataBank.com analysts picked out the ad that listeners in the right demographic would respond to well. The lobbyist gratefully picked up his report and would have the winning spot on the air in Chicago by Monday. "For bigger accounts," Larry told me, "we can move even faster."

\section{B. The Altruists at Astroturf-Lobby.org}

Whereas DataBank.com was a privately held firm, Astroturf-Lobby.org was set up by Mark and Charles to help political action committees (PACs) with Internet communication strategies. The firm has two full stories of a building on Connecticut, along what Charles likes to call the "towers of power" - the corridor of important political consultancies that stretches between the White House and Dupont circle. Mark works especially long shifts. Like TV doctors, he is always on call and will respond quickly if one of the pagers or cell phones on his belt rings. Also like TV doctors, he is on 24-hour rotation periods with his colleagues so someone at the non-profit is always awake to maintain spin control for clients. Although Astroturf-Lobby.org helps PACS from different parts of the political spectrum, Mark finds personal affinity with Republican groups. "I have the same goal as the activists," Mark said. "I'd like to get a million people. I want the Speaker of the House to be able to send an email to a million people about how the latest tax package benefits them. I want to be able to circumvent Peter Jennings." Mark has worked for a number of Republican issues and is particularly angry about how what he calls "the liberal media" spins his campaigns. "Constituents always complain about feeling disconnected from Congress because the media doesn't transmit a GOP politician's message clearly," Mark said. He has met the staff at DataBank.com, but disagrees with their theory that the Internet should be used to draw people into political dialogues.

Mark: These people are assuming that the obstacle to participation is the labor; I think the obstacle is personal interest. Why is it better to have more people participating if their level of interest is so low that they can't even get off their butts to get a stamp and write Washington? Are their opinions really valuable if they can't afford 33 cents for that opinion? If they will blubber in front of the local TV cameras but not be bothered to 
actually vote? Or worse like in Florida, they try to vote but don't take care to learn how the ballot works?

Here Mark reveals the genuine republican sentiment that the most valuable political opinions come from people who are willing to spend time, effort and money to form and express an opinion. Mark used to work as one of Nader's Raiders. He was the key logistical person for the New York City Earth Day of 1990, one of the proudest moments for contemporary environmental activists. Now he works for Astroturf-Lobby.org, a nonprofit set up to help groups with their political advocacy strategies. He says he does not think of himself as a cynical person, and the Earth Day 1990 poster is proudly displayed in his office, but he does seem to have grown in a different direction since taking work as a political consultant.

Mark: There are these idealists who go out and build a website or business around creating democratic reform. There's no business in democratic reform. You gotta represent one side or the other and you gotta help your client win.

One of the clients winning with Mark's assistance is Amnesty International. The organization called one day in early 2001 to make sure the latest details of a torture case were up on its website. Mark stopped mid conversation the instant one of his pagers went off. It had been triggered by a call from Turkey, and was a signal that a fax was coming in with details about an urgent appeal for attention to a case of torture.

Amnesty's agents in Turkey were not equipped with email but could call and fax, so the case history poured out of a fax machine down the hall. Mark ran down, grabbed it off the fax, and walked it one flight up to one of the techies who maintain Amnesty International's "wide-area" communications. The facts of the case were entered into a database, which generated an action alert to everyone on Amnesty's roll who had said they were particularly interested in doing something about torture cases in Turkey. These people, mostly in the US, Canada, UK, and Australia, were sent a form email, a dossier about the case, and a list of contact names, numbers, and addresses of people to target for a letter writing campaign. Journalists around the United States received a special briefing packet. The arrest and torture had begun that night in Turkey; it was 4 p.m. in Washington when Mark's pager went off, and the action alert was formatted and sent out by 5 p.m. On the East coast some members would get home after work to check their email and find the invitation to send either an automatically generated protest letter or one customized by as much activist fervor as they were willing to muster. The fact sheet might have made a few newspaper deadlines on the West Coast.

Astroturf-Lobby.org had activated an issue public. Within 48 hours the letter writing campaign had exposed and embarrassed the Turkish government into releasing the torture victim. This process of bringing digital sunlight to a political problem is championed on the Amnesty International website. ${ }^{3}$ But activating people with bland old text files is not

\footnotetext{
${ }^{3}$ Accessed http://www.amnesty.org/ on 06/2001: “Amnesty International has launched a new online network -- FAST (Fast Action Stops Torture) -- as part of its worldwide campaign to stop torture. As soon as Amnesty International hears about an imminent threat of torture, FAST instantly sends out an alarm to
} 
what excites Mark, and here he reveals that one of his goals is to build as much surveillance and tracking technology into political hypermedia:

Mark: I want to send out "Flash" files full of information - mini political commercials. Now if you forward the email to your friend, this "Flash" file will connect with our server, let us collect the information on the transaction, and update the flash file with the latest information.

With commercially available software, Mark can watch how his members are reacting to political events - what they feel deeply angered by, how quickly they are willing to act, how widely they are willing to draw on their social network, and with whom specifically they correspond. In other words, he can track the affinity network.

Charles, the company's cofounder, is proud of the collection of photos he has on his ego wall: Reagan, Bush senior, Clinton, and Bush junior pose with him at different events; other political personalities, even ones who did not win the offices they chased, are there. One of his favorite stories is of his time as an aide to a senior Senator, who in a quiet moment in the month before retiring thanked Charles for helping him remember everybody's names. Woffard candidly pointed out that he would not remember Charles' name by the end of the month. "With all this new technology, we improve the political memory," Charles tells me. He described the process that political parties have to go through to adapt political hypermedia.

Charles: political positions are always full of contradictions, and we have to manage the paradoxes that become apparent when the party muckitymucks decide to build a website. It comes down to me to juggle the party planks so that the paradoxes aren't as apparent or only appear to someone who does really deep surfing into the site. Before the Internet the important political campaign managers had a kind of speechwriter's role, mediating between the different schools of thought that exist within a campaign. Now we don't have to mediate so much, we just organize the paradoxes so that they don't appear to clash.

Here Charles reveals that political parties actually pay him to help them cloak contradictions in their political platforms. For Astroturf-Lobby.org, this subterfuge is possible by gathering intelligence on a website's visitors and showing them the content from which they are most likely to take satisfaction.

Astroturf Compiler Software. To help manage these contradictions, Charles and Mark developed the Astroturf Compiler, a software package that allows lobbyists to build a sympathetic community of supporters through informational bulletins. The software also

its network of activists around the globe. Cell phones ring, pagers buzz and computers chime, instructing activists by the thousands to sign electronic letters of protest. Within hours, the threat of torture is exposed. Once exposed, it is nearly impossible to carry out.... When you sign up with FAST, you transform your computer, cell phone, handheld or pager into an instant action tool -- a tool with the power to save thousands of people from the horrors of torture. You also become a part of a worldwide community of activists determined to prove that human rights violations can -- and will -- be stopped." 
allows people who are sympathetic with a lobbyists campaign to pass political information along their own networks of friends and family. Whereas a social movement grows when people with grievances meet, agree on a common agenda and organize for political action, the Astroturf Compiler is for lobbyists who already have an agenda, but need to find and organize members of the voting public likely to subscribe to the agenda. Mark has an unusual definition of a democratic "representative." He also says "every issue has a lobbyist," and lobbyists are usually the ones who hire him to find them their supporters.

Mark: The chlorine lobby needs to be able to say 'we represent $\mathrm{X}$ thousand chlorine lovers in America.' I find out how many people in the US love chlorine. We don't always need to contact those people, just need to label them as chlorine lovers, and figure out what districts they are in. To be strong in politics is to have the best quality information about what your constituents want. Being strong in politics makes all other political values possible.

According to Mark, his clients are grateful when he finds sympathetic voters for them, but are just as grateful when he can estimate the number of people they can "legitimately" claim to represent and covertly gather information on these unaware constituents. Given that the firm has grown up through several technologies, I found the organization an ideal site for studying the transition to Internet politics. "One of the important changes I have seen," Mark tells me, "is that these days the thing we are researching and promoting tends to be an issue, not a candidate. They're special interest groups, or special interest groups acting behind a candidate; the object of our promotions is an issue position, rarely a person." He and his staff said they feel that political charisma is rarely salient even in the most high profile debates or electoral contests.

The firm is also interesting because all along the organization has been a valued means of mass customization or narrowcasting. The chief information officer spent most of his time coming up with ways to "slice and dice" data that would reveal new things to customers. Hunched over his computer terminal, he describes how his conclusions about popular opinion can help identify and define groups of people who might be susceptible to "push" or "pull," and those who were susceptible would be sent some political propaganda designed to push or pull that particular person's opinion a specific way. "We don't actually generate the content, that's up to the campaigns. But I can tell a campaign what Citizen Q would like to hear, and what his address is. I can also hand over his phone number and sometimes an email address," said Mark, who put a spin on how he described these applications. This set of software applications, however, is not just a benign system of giving voice to people whose opinions have not been counted. Lobbyists who use the Astroturf package can actively change the political landscape and influence representatives. They not only get more accurate information, they actively agitate on issues and then forward the results of that agitation, still relying on money and technology to influence legislators. 
VoteMover. The VoteMover software is based on a set of algorithms that relate campaign expenditures, constituent correspondence with elected officials, and legislative outcomes. These relationships vary by policy topic, so good poll data helps the staff at Astroturf-Lobby.org keep algorithms up to date so that they can trigger and direct phone calls, emails, and telegrams from the right constituents at the right time to the right elected officials. "A good poll is a plebiscite" was the first declarative statement Charles made for my notation as he put his feet on the desk on my first day with the organization. The offices always seemed dark, and in his large front office I realized why. He explained that they had double paned and shaded the windows to prevent too much sound or light within the building from escaping to snooping instruments outside. "Polls and plebiscites used to be expensive, but now we can run them over the Internet. More important, we can start to anticipate public opinion as long as the data sets are kept fresh." Almost every person I spoke to in the firm, including a couple of its clients, were convinced that the top political leaders relied on polling numbers to lead them. Some thought it was an unfortunate dependency, but other argued that we would all be better off with more "positive and negative feedback loops" between leaders and citizens, "clear signals of approval and disapproval" and building "direct connections between leadership and lead." Still, one of the major locations of blockage in the political system, according to Mark, is the Legislature itself. "Take hand gun control," he offers. "Seventy percent of Americans want tighter gun controls, but the political system has been incapable of meeting that public demand." This problem can be resolved, he thinks, by giving activists and lobbyists the tools to channel public opinion at strategic places and important times. But here is where Charles and Mark disagree. Whereas Charles thinks a seasoned political consultant will know how to best strategize campaign communications, Mark wants to make use of as many statistics as possible to model political life. ${ }^{4}$

If a campaign comes to them with clear legislative goals, Mark applies a range of analytical and statistical tools to figure out which members of Congress will be most sensitive to constituent mail, and the degree of the sensitivity. The company has done enough campaigns so that it can roughly predict the rise and fall of public attention, journalistic attention, and Congressional attention. But if the campaign can tell them how many votes they need to move in Congress, Mark can make more precise calculations about how many letters, phone calls, emails, and telegrams need to be thrown at each member of Congress. Mark spent last summer going through all of the company's records to catalogue all of the "campaign inputs," such as campaign dollars, financial contributions, television advertising minutes, website banner ads, and phone calls. Then

\footnotetext{
${ }^{4}$ In one real-world example, the National Education Association, nervous that Congress would slash funding for education in the fiscal 1999 budget, took on the Juno Advocacy Network and Pam Fielding of e-Advocates to help turn around the campaign. Of Juno's 6 million subscribers nationwide, 225,000 met both the geographic and demographic criteria of the new effort: parents in key districts who might be concerned about education. These parents wrote 20,000 emails, and education won a 12-percent budget increase. Certainly there was a larger context to the turnaround, but campaign insiders credit the targeted email campaign. Citizens who take advantage of the basic, free email service of Juno Online must fill out an extensive demographic and psychographic questionnaire, which is then used to target advertisements they see as they read and write email: "Send Your Child to a 21 st Century School," "Tell Congress to Support Education," and "Act Now" in rotating banners.
} 
he compared all of the "citizen outputs," such as telegrams, letters, phone calls, petition signatures, emails, and office visits. He even put in data on the particular members of Congress involved, such as size of mandate, length of experience, party, and region of the country.

Since Mark can then purchase data from DataBank.com on the profile of particular districts, he can estimate what resources the campaign will need to bring to bear to leverage specific members of Congress. Mapped onto a list of the campaigns he and his clients considered successful, Mark presents potential clients with a set of formulas for political "wins." He knows the company would never take on big tobacco or military contracts, but he also knows that Mark has a broader definition of what counts as a "progressive cause" than he did when he was working for Nader. Charles is also a hacktivist, who spends time at night, he admits, undoing some of the damage he does during the day by helping people and issues he considers to be marginal and ill equipped to battle with the big guns of political hypermedia.

Mark: I think politics has always been driven by data; it's just that the data on the electorate was never very accurate. The reason traditional politics has been about class or race politics is because individual policy preferences could only be meaningfully categorized by class or race. Now I can differentiate between 9 gradations of nose-pickers, and political culture produced over new media is going to have the same nuances . . . or is it fragments?

Charles: I've been with this consulting house for almost 20 years. When we produce a political campaign today, it tends to be about consumption and lifestyle issues, not about class politics. More important, we use the new media to produce issues, not leaders. Leadership roles shift from issue to issue and the political faces we use on one issue are different from the ones we use on other issues. We create issue-specific leaders, and they rarely have purchase outside their issue. Not like the old days of party umbrella politics.

Sometimes Mark is seconded to campaigns for significant chunks of time. He is valued for his skills in bringing campaign communications and organizational structures into the $21^{\text {st }}$ Century. The real political change is not happening on the Internet, but because of the Internet, Mark says. Mark: "It allows us to communicate and collaborate with others remotely. We're aware of what is going on around the HQ and the broader campaign without leaving the room." The folks who really make a difference in their campaigns look at the Internet as a tool that should be integrated within the entire campaign communication and organizational structure.

\section{The Production of Modern Political Culture}

"By 2050 a piece of software will be a candidate." 


\section{--Tracey Westin, DemocracyNet.org (now Grassroots.com)}

There has been a long term trend toward rising costs in election campaigning, growing power of advertising managers and publicity experts within the campaign hierarchies, and integration of scientific public policy polls (Agranoff, 1976; Bloom, 1973; Chagall, 1981; Felknor, 1992; Jamieson, 1992; Luntz, 1988; Mauser, 1983; Sabato, 1981; West, 1993; Westbrook, 1983). Producing political culture involves defining a problem and then delineating the issue public that is simultaneously an audience, an aggrieved population, and an impetus for action. Whereas mass media could only communicate within large geographically bounded issues publics - either territorial or demographic, the Internet is used to target issue publics on the basis of shared political preferences. Lobbyists use the political hypermedia to help the issue publics grow and discover themselves, and to activate the issue public as necessary. Like firms that build community around product identity to promote customer loyalty, political parties and lobbyists are using political hypermedia to build brand community. These communities are both a risk and a benefit for the interest groups who seed them. On the one hand, hypermedia communities operate without the information gaps that encumber traditional political parties and these communities may be more difficult to manipulate. On the other hand, they can be quickly activated to advocate for a fairly specific policy option.

This system of political hypermedia brings more producers of political culture to the field. By designing these tools, this professional community broke the monopolistic control of several important media systems -- those that design, distribute, and assess the impact of political culture. Candidate campaign teams, issue group workers, and individuals hacking at home have access to many of the same data sources.

Some political hypermedia tools are specifically for candidates and leaders to produce political culture, improve campaign efficiency, and track public opinion. In describing an application to a political client, Mark described the ability to "virtually walk the precinct." The customization of technologies allows a campaign to produce content from guesses, calculations, or genuine foreknowledge of likely public interests. Businesses like DataBank.com have built relatively cheap tools for citizens to organize their own campaigns, read public opinion, and track the behavior of their elected representatives. However, tracking the behavior of the non-elected representatives - lobbyists who have become a key basis of representation - remains difficult.

Political hypermedia are designed to foreground issues and background candidates. Mass customization or narrowcasting helps draw out information about individual preferences in such a way as to tailor the production of political culture. But in many ways, political hypermedia equip constituents with the same communication tools available to elected officials. The medium allows people to form their own political groups, and these groups have exercised their own patterns of control over political content, group maintenance, and recruitment, even though the groups are conducted entirely online (Hill, 1997). 


\section{A. The Science of Private Opinion Measurement}

Consultants like those working at DataBank.com and Astroturf-Lobby.org designed political hypermedia to enact the principles of direct democracy through constant canvassing. As an invention, the microscope radically altered the way scientists understood the world. Old theories could be tested anew, and our knowledge of the microbiological worlds increased significantly. In the same way, political hypermedia has altered the way political consultants, politicians, and academics understand voter behavior and the relationship between candidates and constituencies. Leaders' comments, committee votes, and fundraising efforts get recorded and catalogued, while the subtle eddies of public opinion get regularly monitored. The consulting industry's ability to predict outcomes has improved dramatically through politically hypermedia, by refining the formula for legislative success, testing political messages, and studying personality psychographics on top of demographics. As Larry from DataBank.com said, "This truly is a new kind of political science." Such detailed knowledge about individuals is used to exercise panoptical and discursive power (Foucault, 1977, 1999; Poster, 1990, 1995), and through Larry, Dave, Mark, Charles and Sally we see that political hypermedia are deliberately designed to exercise panoptical and discursive power. Some scholars have argued that the modern state has by definition been given a duty to surveil its citizenry (Giddens, 1987; Scott, 1998; Webster, 1995). However, we should not uncritically accept that lobbyists and political consultants are in some way part of a legitimate state surveillance apparatus.

Many of the professional new media communications consultants believe that the more data they can collect on citizens and candidates, the more transparent the dyadic relationship between them will become. Citizens will read candidates properly and candidates will read citizens properly. There always have been pollsters and focus groups, but their work is now more of a science. These tools can empower people and groups outside the Beltway but they also make the work of political insiders easier. Citizen attributes were once the quietly held property of citizens. Now these attributes are quantified, bought, sold, and analyzed on a massive, yet personal, scale.

Charles: On the one hand, you want politicians to make their public policy decisions informed by public opinion, but the data is usually used for persuasion, activation, you know 'what rhetoric will scare voters because they hate my opponent,' which is not truly civic. That's the rub.

Even though banner ads are no longer a major source of revenue for advertisers, along with cookies they do help interested parties collect information about the people who use political hypermedia by allowing website designers to follow your route through cyberspace. They allow organizations to track users and their habits and create relational profiles for use as marketing tools. The profiles help users search for the ideal customers for their cultural products. The technology also allows political parties to gather information on where web surfers are going, analyze that data to figure out what their 
ideological leanings might be, and target ads to the web pages they visit. They learn about how their members learn. ${ }^{5}$

And for the most part, this political science is being perfected through private experiments conducted under contract for larger polling houses, lobby groups, and political candidates. Of course, what makes the experimentation possible is the large sample size of some email and web-based survey instruments. While statisticians refuse to say that a particular sample size is needed to justify the claim a survey is 'scientific,' the more cases in a survey, the tighter the confidence interval. Some survey houses maintain panels of hundreds of thousands of people, allowing for both tight confidence intervals and experimentation. "It's the difference between buying 100 lottery tickets and 100,000 lottery tickets," Mark told me. Some have likened the evolution of political hypermedia to the progression of scientific method out of alchemy. Political consultants always looked for the mysterious relationship between television audience reaction and voter approval, but that was unmethodical alchemy compared to research using political hypermedia:

Dave: There is a big hole in our industry's ability to credibly describe that branding or messaging capability. But the television world has had a lot longer to develop it, and there is a language that is used between the people who make the commercials and the people who measure their effectiveness to the point now where you know that if you place 1,000 gross rating points in this market with this message, you are going to move public opinion X. And so, 1,000 GRPs actually means something to public opinion. But we are already starting to develop the metric for predicting the effect of 1 million impressions.

Several managers found that it was better to test hypotheses and float ideas over political hypermedia rather than speculate about how political spin might be received by the public. Recall the message tester tool that Astroturf.org developed - the goal has been political communication tools that forecast voter reaction and anticipates voter desires.

Dave: The science of building relational databases was pioneered by the marketing and sales folks. That's all those companies have to make

\footnotetext{
${ }^{5}$ Many Republican and Democrat consultants share these attitudes equally. For example, a Republican consultant said: "What's fundamentally different from TV, radio, and the newspaper, is that we are able to measure who got it, how often they got it. You could never do a real reception study. Now we can tell who saw what and how long they took to read it. The Internet stuff has an ability to measure, even with protecting individual privacy. Nielson ratings are grossly imprecise in comparison. I think the world in which you are able to understand what the public is thinking is a better political world. But bad analysis from good or bad data is still bad analysis." For example, a Democrat consultant said: "Bumper stickers don't get people to vote. Name recognition, excitement over issues, controversy, and leadership do get people to vote. The new tools may help generate excitement. We may be able to excite people more easily if you target the right people. It's cool to do that - to reach the right people at the right time about the right issues. No question about it, the targeting science is getting much better. To get this response, you need to start off with this kind of raw numbers. We make the parallel with telephone sales: have 50 phone calls, you'll have 10 conversations, and 2 will be a serious discussion, and 1 will buy. Just like direct mail. This stuff isn't being reinvented. It's being perfected!"
} 
money from: zip codes, street addresses, names cross-referenced with credit card data. Even if your website doesn't register people, tracking cookies adds new scalable layers to a relational database.

Both Converse and Herbst have charted the changing meaning of public opinion, finding that legislative staff, activists, and journalists evaluate whatever data is presented as "public opinion" and rely on interest groups and media for interpretation (Herbst, 1998). In this way, community notables were responsible for framing public opinion (Herbst, 1998). The issue publics now play this role, as small elites who compile specific data on public opinion for presentation to leaders and, ironically, the public. "Clearly a sample design which extracts unrelated individuals from the whole and assigns the opinion of each an equal weight is a travesty on any 'realistic' understanding of what the concept of public opinion means" (Converse, 1987), p. S14). However, since Internet technologies allow unequal weightings and complex layerings of data, it is increasingly possible to draw complex pictures of an issue public. Whereas the public opinion of old was calculated on the equal weighting of responses, in the sense of one person, one vote, contemporary public opinion is based on the notion that the public opinion consists of small issue publics made up of stakeholders with substantive interests or power and excluding others.

Surveyors have always found people to make remarks that make it difficult to categorize them as consistently liberal or conservative. In addition, respondents express ambivalence or difficulty in making up their minds, or they make a distinction between their preference and how they want their answer to recorded. In other words, there are big differences between an individual's policy preferences and what they reveal as traditional survey respondents. Interviewer effects, instrument effects, treatment effects, reference effects, priming effects of news, and framing effects all serve to cloud the measurement of public opinion (Zaller \& Feldman, 1992). Moreover, even when those effects can be known or controlled, respondents are usually not politically sophisticated, repeat misinformation and propaganda, and are unable to make decisions about policy trade-offs (Delli Carpini \& Keeter, 1996; Ferejohn \& Kuklinski, 1990).

\section{B. Thin Citizenship and Data Shadows}

The social contract is renewed whenever we vote or engage in political activities, but imperfect information prevents citizens from understanding their roles, their leadership choices, or their leader's choices. Imperfect information also prevents leaders from understanding the policy preferences of citizens. To solve the problem of imperfect information, several companies set out to design communication tools that would better help candidates and campaigns produce political culture. The production of political culture through Internet technologies is a process of tailoring content not for mass consumption, but for private consumption. In e-commerce the parallels are obvious "mass customization," "broadcast individualism," and "direct marketing" are all terms that apply as much to how political icons, arguments, and actors are marketed. 
Thin Citizenship. Political hypermedia has been designed to permit, and promote, a thinned citizenship role for members of the social contract. One member of the professional community made a nice parallel between the new kind of citizenship and the current fashion in computing network management in describing the latest trend for large offices to set up "thin clients" - computers that have very little resident software but are connected to a large memory resource in which all the organization's software and documents are stored. In the same way, political hypermedia are designed for thin citizenship, a role that does not require individuals to have their own active, engaged political memory because they can quickly respond to poll questions that present simplified policy options. The thin citizen responds quickly to political urges, but does not spend significant amounts of time contemplating politics. Says one respondent, from the Dole '96 campaign,

This is not a democracy. These people do not think about this stuff 24 hours a day, seven days a week. People don't want to think about this shit all the time. They want to have a life. They want to go out. They want to go out to movies, hang with their friends, and go home. They don't want to spend Friday night sitting in front of a computer screen figuring out George Bush's Social Security policy (Jagoda, 2000), p. 96).

Deliberately thinned citizenship makes it difficult to proscribe broad institutional means of servicing individual grievances. Indeed, since democratic governments are designed to redress collective grievances, thinning citizenship leaves fewer generalizable cues and minimal moral benchmarks. Political hypermedia are designed to deny universal, collective needs and to accept diverse individual needs. Moreover, the Internet allows a campaign to measure and weight levels of political commitment, especially fractional levels of support that never translate into financial contributions or voter commitment.

For example, during the 2000 campaigns the Sierra Club was particularly excited about getting more "light greens" through its Internet strategies. These were new members who passionately wanted to preserve a local species, but didn't think of themselves as environmentalists or subscribe to a larger environmentalist agenda. Here mark reveals that the Sierra Club could expand its membership base by thinning its expectations of a membership role from active engagement (volunteering and donating) to a carefully calculated threshold of "elected affinity."

While political hypermedia can be used by social movements to organize, or by organizations to build a social movement, the media can also be used to form other issue publics - tiny groups of like-minded people who are not interested in building a membership, and only interested in advocacy. One of the peculiar new phenomena of the 2000 campaign were the IRS classified 527s, charities that accept money and spend it on behalf of a candidate or partisan issue, but have no palpable membership. The corollary to a social contract with thinning citizenship responsibilities, however, is that in some way collating and anticipating public opinion is necessary. The thin citizen only irregularly connects to contribute to a policy discourse and, when they do, it is for a 
briefly considered contribution on a selected issue. The rest of their formal contribution is made by their data shadow.

Data Shadows. Some political philosophers have made a distinction between our private and public lives. "Nothing is more dangerous than the influence of private interests on public affairs," wrote Rousseau in Book III of the Social Contract. Through active engagement in a political community the citizen evolves "a second life, a moral life, which is not his sole possession, but whose reality depends on the continued existence of his fellow-citizens and of their association." (Rousseau in (Westbrook, 1983) Political hypermedia creates this second life for us, but this life is a construct of data that is not in our possession. It is a shadow of our selves, composed by a raw record of how we think and act in our private worlds.

In their study of popular culture systems, Horkheimer and Adorno concluded "individuals have ceased to be themselves and are now merely centers where the general tendencies meet" (Horkheimer \& Adorno, 1997). This might have been true for the mass media systems they were observing, but the Internet systems are designed to track and locate more individualistic tendencies.

Larry: The American public has outsourced their democracy to a class and elite that is active in politics - politicians, members of the media, think tanks, and political consultants. Every two years and a third of the senate and every four years for the President, the people renew this contract.

Between these formal elections, the digital shadow is consulted by the social elites active in politics, whether these elites claim to be industry lobbyists or grassroots activists. The technical solution provided by this community of consultants, envisioned at conferences and dinners in the Childe Herold pub, is to direct as much political discourse through the new tools of political hypermedia. The problem with the democratic institutions set up by the social contract is that the parties to the contract - the governed and the governing did not have suitable tools for supervising compliance.

We often cast a data shadow when we complete an electronic purchase, browse web sites or agree to participate in a survey. The data shadow follows us almost everywhere. It represents us by profile, but with little color. We are not always aware of its appearance, but others can note the silhouette. It is the silhouette created by our daily activities, and it is one of the parties to the new digitized social contract. Some people have more crisply defined data shadows, depending on how many political hypermedia they interact with. Credit card purchases, voter registration records, polling data, and magazine subscriptions all help create the data shadow. Increasingly, the data shadow represents us in political discourse. The data shadow has become an important political actor.

Data shadows not only follow citizens, but political candidates, and institutions cast them as well. Few people can effectively op-out of their digital shadow. Political hypermedia consultants have imagined shadow governments, a term familiar to those in parliamentary 
democracies, where the opponents of primary power holders meet to discuss policy alternatives and closely regulate their counterparts who have the real power (Alpert, 2000). So many of the new media technologies get mined for data - even those not designed to expressly collect political information, that our data shadows inevitably generate political information. Political lives are constructed from the bytes we leave behind us, for use by a range of authorities, some we might consider legitimate, others we are not aware of but who claim to represent us.

\section{Conclusion}

An immense source of power lies in the ability to produce political culture. An effective political campaign is about defining and acknowledging the stakeholders, framing arguments, and creating icons, and all three of these kinds of political objects are much easier to manage using the new communications tools developed over the last decade. Information is still power, but having raw data does not a king make. Instead, it is the careful production of political culture through the manipulation of data that makes political power. This data is used to produce opportunities for exercises in thin citizenship and to produce data shadows for occasions where citizens are not engaged but need representation on a specific issue. In this article I have sought to understand the professional norms of those who build political hypermedia, and to set out the design principles of system of political hypermedia we now inhabit. I have also sought to be critical of these norms and design principles, building a critique of the science of private opinion measurement, data shadows and thin citizenship.

The cases of DataBank.com and Astroturf-Lobby.org reveal what many consultants consider to be 'new' about the political culture produced over hypermedia. (1) Traditionally, the industry focused on basic demographic categories like race, class and gender, whereas now the industry can create much more subtle factions based on demographics, psychographics and opinion. (2) Traditionally, their political masters employed them to advance candidates by marketing desirable qualities of character because strong political character would bring stability in a world of fleeting political issues, whereas now the consultants find that the political characters are fleeting, and that as consultants they are retained to maintain permanent campaigns on lasting issue positions.

Much of what has been revealed here about how political culture is produced would be difficult to expose with surveys of voter sophistication, news consumption patterns, or habits of learning about politics. Certainly these are important trends to watch, but it may be a while before the 'media effects' on individual behavior are manifest. The theories about political culture explored here can inform the study of individual behavior. Is the wired citizen engaged with more topics of political debate, but less involved and less knowledgeable about any particular topic? How many legislators rely on models of voter preference from lobbyists and data mining companies? How is our digital shadow an accurate trace of our policy preferences, and how can a polity of thinned citizenship roles remain healthy? The implications of thinned citizenship roles and data shadows are 
profound, and we must continue to assess trends in political communication both in terms of individual voter behavior and the larger character of political culture. 


\section{References}

Accenture. (2001). Egovernment Leadership: Rhetoric Vs Reality - Closing the Gap (17).

Chicago: Accenture.

Agranoff, R. (1976). The Management of Election Campaigns. Boston.

Alexander, C. J., \& Pal, L. A. (1998). Digital Democracy: Policy and Politics in the Wired World. Toronto: Oxford University Press.

Alpert, M. (2000). Why Not Create a Shadow Government. Z Magazine, 13, 1315.

Anderson, B. R. O. G. (1991). Imagined Communities : Reflections on the Origin and Spread of Nationalism (Rev. ed.). London; New York: Verso.

Arterton, F. C., \& Roosevelt Center for American Policy Studies. (1987). Teledemocracy : Can

Technology Protect Democracy? Newbury Park, Calif.

[Washington, D.C.]: Sage Publications ;

Roosevelt Center for American Policy Studies.

Barney, D. (2000). Prometheus Wired: The Hope for Democracy in the Age of Network

Technology: University of Chicago Press.

Bartels, L. (1996). Uninformed Votes: Information Effects in Presidential Elections. American Journal of Political Science, 40(1).

Behr, R. (1985). "Television News, Real World Cues, and Changes in the Public Agenda ". 49.

Beniger, J. (1987). Personalization of Mass Media and the Growth of Pseudo-Community (Vol.

14, pp. 352-371): Communication Research.

Bennett, D., \& Fielding, P. (1999). The Net Effect: How Cyberadvocacy Is Changing the Political Landscape. Washington, DC: Capitol Advantage.

Bennett, S. (1988). Know-Nothings' Revisited: The Meaning of Political Ignorance Today. Social Science Quarterly, 69.

Bimber, B. (1998). Three Faces of Technological Determinism. In L. Marx (Ed.), Does

Technology Drive History? The Dilemma of Technological Determinism (pp. 79-100). Cambridge, MA: MIT Press.

Bloom, M. (1973). Public Relations and Presidential Campaigns: A Crisis in Democracy. New

York.

Brants, K., Huizenga, M., \& van Meerten, R. (1996). The New Canals of Amsterdam: An

Exercise in Local Electronic Democracy. Media, Culture and Society, 18, 233-247.

Budge, I. (1996). The New Challenge of Direct Democracy: Polity Press.

Burbank, M. (1997). Explaining Contextual Effects on Vote Choice (Vol. 19, pp. 113-132):

Political Behavior.

Calhoun, C. (1998). Community without Propinquity Revisited: Communications Technology

and the Transformation of the Urban Public Sphere. Sociological Inquiry, 68(3), 373-397.

Chagall, D. (1981). The New Kingmakers. New York.

Clark, T. N., Hoffmann-Martinot, V., \& Gromala, M. (1998). The New Political Culture. Boulder, Colo.: Westview Press.

Clift, S. (2000). In P. Howard (Ed.). Los Angeles.

Converse, P. E. (1987). Changing Conceptions of Public-Opinion in the Political-Process. Public Opinion Quarterly, 51(4), S12-S24. Institute.

Corrado, A. (1996). Elections in Cyberspace: Toward a New Era in American Politics: Aspen

Dahl, R. A. (1989). Democracy and Its Critics. New Haven: Yale University Press.

Davis, R., \& Owen, D. (1998). New Media and American Politics: Oxford University Press.

Delli Carpini, M. X., \& Keeter, S. (1996). What Americans Know About Politics and Why It

Matters. New Haven, [Conn.]: Yale University Press.

Dijk, J. v., \& Hacker, K. L. (2000). Digital Democracy : Issues of Theory and Practice. London: Sage.

DiMaggio, P., Hargittai, E., Neuman, R., \& Robinson, J. (2001). Social Implications of the Internet. Annual Review of Sociology, 27, 307-336. 
Downing, J. (1989). Computers for Political Change: Peacenet and Public Data Access. Journal of Communication, 39, 154-162.

Downing, J. (1991). Computers for Social Change and Community Organizing. New York: Haworth Press.

Drinkard, J. (1999). E-Politics: How the Internet Is Transforming Grassroots Campaigns. USA Today, pp. 1 .

Etzioni, A. (2000). Debating the Societal Effects of the Internet: Connecting with the World. Public Perspective, 11(3), 43-43. Routledge.

Everard, J. (2000). Virtual States: The Internet and the Boundaries of the Nation-State. London:

Fallows, J. (1996). Breaking the News: How the Media Undermine American Democracy.

Faucheux, R. (1998). How Campaigns Are Using the Internet: An Exclusive Nationwide Survey. Campaigns and Elections, 19(9), 22-25.

York.

Felknor, B. (1992). Political Mischief: Smear, Sabotage, and Reform in U.S. Elections. New

Ferdinand, P. (Ed.). (2001). The Internet, Democracy and Democratization. London: Frank Cass. Ferejohn, J. A., \& Kuklinski, J. H. (1990). Information and Democratic Processes. Urbana:

University of Illinois Press.

Foucault, M. (1977). Discipline and Punish : The Birth of the Prison (1st American ed.). New York: Pantheon Books.

Foucault, M. (1999). Power as Knowledge. In C. Lemert (Ed.), Social Theory, the Multicultural and Classic Readings' (pp. 475-481): Westview Press. $\underline{18}, 185-212$.

Friedland, L. (1996). Electronic Democracy and the New Citizenship. Media, Culture and Society,

Ganly, G. (1991). Power to the People Via Personal Electronic Media. The Washington Quarterly,

Press.

Giddens, A. (1987). Social Theory and Modern Sociology. Stanford, Calif.: Stanford University

Goldschmidt, K. (2001). Email Overload in Congress: Managing a Communications Crisis.

Washington, DC: Congress Online Project.

Graber, D. A. (1996). The 'New' Media and Politics: What Does the Future Hold? PS: Political

Science \& Politics, 29(1), 157-168. Routledge.

Gray, C. H. (2001). Cyborg Citizen : Politics in the Posthuman Age. New York ; London:

Groper, R. (1996). Electronic Mail and the Reinvogoration of American Democracy. Social Science Computer Review, 14(2), 157-168. Penguin.

Grossman, L. (1996). The Electronic Republic : Reshaping Democracy in the Information Age:

Gutstein, D. (1999). E.Con. Toronto: Stoddart.

Habermas, J. (1991). The Structural Transformation of the Public Sphere: MIT University Press.

Hacker, K. (1996). Missing Links: The Evolution of Electronic Democratization. Media, Culture and Society, 18, 213-232.

Hague, B. N., \& Loader, B. (1999). Digital Democracy: Discourse and Decision Making in the

Information Age. London; New York: Routledge.

Heclo, H. (1999). Hyperdemocracy: The Wilson Quarterly.

Herbst, S. (1998). Reading Public Opinion : How Political Actors View the Democratic Process.

Chicago: University of Chicago Press.

Hill, K. (1997). Computer Mediated Political Communication: The Usenet and Political

Communities (pp. 27-Mar): Political Communication.

Hill, S., \& Hughes, J. G. (1997). Computer Mediated Political Communication: The Usenet and

Political Communities. Political Communication, 14, 3-27.

Horkheimer, M., \& Adorno, T. W. (1997). Dialectic of Enlightenment. New York: Continuum.

Howard, P. N. (2002). Network Ethnography and the Hypermedia Organization: New Media,

New Organizations, New Methods. New Media \& Society, 4(4), 550-574.

Howard, P. N., Jones, S., \& Rainie, L. H. (2001). Days and Nights on the Internet: The Impact of

a Diffusing Technology. American Behavioral Scientist, 45, 382-404. 
Ireland, E., \& Nash, P. T. (2001). Winning Campaigns Online: Strategies for Candidates and Causes. Bethesda, Maryland: Science Writers Press.

Jagoda, K. (2000). E-Voter Study 2000: Measuring the Effectiveness of the Internet in Election

2000. Washington, DC: E-Voter Institute.

Jagoda, K., \& Nyhan, N. (1999). E-Voter 98: Measuring the Impact of Online Advertising for a

Political Candidate. Washington, DC: Westhill Partners.

Jamieson, K. (1992). Packaging the Presidency: A Historical and Criticism of Presidential

Campaign Advertising. New York.

Kamarck, E. C., Nye, J. S., \& Visions of Governance in the 21st Century (Program). (2002).

Governance.Com : Democracy in the Information Age. Cambridge, Mass.

Washington, D.C.: Visions of Governance in the 21st Century ;

Brookings Institution Press.

Katz, E. (1992). On Parenting a Paradigm: Gabriel Tarde's Agenda for Opinion and

Communication Research. International Journal of Public Opinion Research, 4, 80-85.

Kidder, T. (1981). The Soul of a New Machine. Boston: Little Brown.

Kraut, R., Patterson, M., Lundmark, V., Kiesler, S., Mukopadhyay, T., \& Scherlis, W. (1998).

Internet Paradox - a Social Technology That Reduces Social Involvement and Psychological Well-Being? American Psychologist, 53(9), 1017-1031.

Lazarsfeld, P., \& Merton, R. (1948). Mass-Communication, Popular Taste, and Organized Social

Action. In L. Bryson (Ed.), The Communication of Ideas (pp. 95-118). New York: Harper \& Brothers.

Magazine. Lewis, M. (2001). The Two-Bucks-a-Minute Democracy. Ny Times Magazine. NY Times

Luntz, F. (1988). Candidates, Consultants and Campaigns the Style and Substance of American

Electioneering: Oxford.

Lupia, A. (1994). Short Cuts Versus Encyclopedias: Information and Voting Behavior in

California Insurance Reform Elections (Vol. 88): American Political Science Review.

MacKuen, M. (1984). " Exposure to Information, Belief Integration, and Individual

Responsiveness to Agenda Change " (Vol. 78): American Political Science Review.

Margolis, M. (1997). Campaigning on the Internet: Parties and Candidates on the World Wide

Web in the 1996 Primary Season (Vol. 2): Harvard International Journal of Press/Politics.

Mauser, G. (1983). Political Marketing: An Approach to Campaign Strategy. New York.

McGrath, M. (2000). Wired for Civic Engagement: Using New Technology to Build Community.

National Civic Review`, 89(3).

Mele, C. (1999). Cyberspace and Disadvantaged Communities: The Internet as a Tool for

Collective Action. In P. Kollock (Ed.), Communities in Cyberspace (pp. 290-310): Routledge.

Merton, R. K., Lowenthal, M. F., \& Curtis, A. (1946). Mass Persuasion : The Social Psychology

of a War Bond Drive. New York: Harper.

Milban, D. (1999, July 5). Virtual Politics. New Republic.

Miles, S. (2001). How to Hack a Party Line: The Democrats and Silicon Valley (1st ed.). New

York: Farrar Straus and Giroux.

Miller, N. (1986). Information, Electorates, and Democracy: Some Extensions and Interpretations

of the Condorcet Jury Theorem. In G. Owen (Ed.), Information Pooling and Group Decision Making.

Greenwich, Conn.: JAI.

Moll, M., \& Shade, L. (Eds.). (2001). E-Commerce Vs. E-Commons: Communications in the

Public Interest. Ottawa: Canadian Centre for Policy Alternatives.

Moore, D. (1987). Political Campaigns and the Knowledge-Gap Hypothesis. Public Opinion

Quarterly, 51(2), 186-200.

Multiple. (1999). Technology: How Is It Changing Grassroots Lobbying Strategies. Campaigns \&

Elections. Campaigns and Elections, 20.

Mutz, D. (1995). Effects of Horse-Race Coverage on Campaign Coffers: Strategic Contributing in

Presidential Primaries (Vol. 57, pp. 1015-1042): Journal of Politics.

Nie, N., \& Erbring, L. (2000). Our Shrinking Social Universe. Public Perspective, 11(3), 44-45.

Norman, D. (1989). The Design of Everyday Things. New York: Basic Books.

Norris, P. (2000). A Virtuous Circle : Political Communications in Postindustrial Societies.

Cambridge, UK ; New York, NY, USA: Cambridge University Press. 
Ogburn, W. (1937). The Influence of Inventions on American Social Institutions in the Future. American Journal of Sociology, 43(3).

Palfrey, T., \& Poole, K. (1987). The Relationship between Information, Ideology and Voting

Behavior. American Journal of Political Science, 31, 511-530.

Poster, M. (1990). The Mode of Information: Polity Press.

Poster, M. (1995). The Second Media Age: Polity Press.

Putnam, R. D. (2000). Bowling Alone: The Collapse and Revival of American Community. New York: Simon \& Schuster.

Ransell, E. (1999). Democracy Is an Interactive Form of Government: Tracey Western. Fast Company, 302

Rash, W. (1997). Politics on the Nets : Wiring the Political Process: W.H. Freeman.

Redd, L. (1988). " Telecommunications, Ecoomics and Black Families in America " (Vol. 19, pp. 111-123): Journal of Black Studies. Wesley Pub.

Rheingold, H. (1993). Virtual Community: Homesteading on the Electronic Frontier: AddisonPublishing.

Rheingold, H. (2002). Smart Mobs : The Next Social Revolution. Cambridge, MA: Perseus

Sabato, L. (1981). The Rise of Political Consultants: New Ways of Winning Elections. New

York: Basic Books.

Schwartz, E. (1996). Netactivism: How Citizens Use the Internet: Songline Studies.

Scott, J. C. (1998). Seeing Like a State : How Certain Schemes to Improve the Human Condition Have Failed. New Haven, Conn.: Yale University Press.

Shapiro, C. (1999). Information Rules: A Strategic Guide to the Network Economy. Cambridge,

Mass: Harvard Business School Press.

Sunstein, C. R. (2001). Republic.Com. Princeton, N.J.: Princeton University Press.

Tambini, D. (1999). New Media and Democracy: The Civic Networking Movement. New Media \& Society, 1(3), 305-329.

Tarde, G. (1898). Opinion and Conversation. L'opinion Et La Foule. Paris: Alcan.

Taylor, H. (2000). Does Internet Research Work? International Journal of Market Research, 42(1), $51-63$.

Tehranian, M. (1990). Technologies of Power: Information Machines and Democratic Prospects. Norwood, NJ: Ablex Publishing.

Tichenor, P., Donohue, G., \& Olien, C. (1970). Mass Media Flow and Differential Growth in

Knowledge. Public Opinion Quarterly, 34(2), 159-170.

Toffler, A. (1990). Powershift : Knowledge, Wealth, and Violence at the Edge of the 21st Century.

New York: Bantam Books.

Toffler, A., \& Toffler, H. (1995). Creating a New Civilization: The Politics of the Third Wave.

Atlanta: Turner Pub.

Tsagarousianou, R., Tambini, D., \& Bryan, C. (1998). Cyberdemocracy: Technology, Cities, and

Civic Networks. London; New York: Routledge.

Tumber, H., \& Bromley, M. (1998). Virtual Soundbites: Political Communication in Cyberspace.

Media Culture \& Society, 20(1), 159-167.

Walch, J. (1999). In the Net: An Internet Guide for Activists. London: Zed Books.

Wasserman, E. (1999). Some Tips for Selling Presidents Online: The Making of the President

Has Turned into an E-Business. The Industry Standard', 20-21.

Webster, F. (1995). Theories of the Information Society: Routledge.

West, D. (1993). Air Wars: Television Advertising in Election Campaigns, 1952-1992.

Washington, DC.

Westbrook, R. (1983). Politics as Consumption: Marketing the Modern American Election. In T.

J. J. Lears (Ed.), The Culture of Consumption (pp. 143-173). New York.

Witte, J., \& Howard, P. N. (2002). The Future of Polling: Relational Inference and the

Development of Internet Survey Instruments. In B. Page (Ed.), Navigating Public Opinion: Polls, Policy

and the Future of American Democracy. New York: Oxford University Press.

Wittig, M., \& Schmitz, J. (1996). Electronic Grassroots Organizing. Journal of Social Issues, 52(1), 53-69.

Wright, R. (1995, January 23, 1995). Hyperdemocracy. Time Magazine, 15-21. 
Page 32 of 32

Zaller, J., \& Feldman, S. (1992). A Simple Theory of the Survey Response: Answering Questions Versus Revealing Preferences. American Journal of Political Science, 36(3), 579-616. 